\title{
Analisis Faktor-faktor yang Mempengaruhi Indeks Pembangunan Manusia Kabupaten Malang Berbasis Pendekatan Perwilayahan dan Regresi Panel
}

\section{Analysis on Factors that Influence the Human Development Index of Malang Regency based on Regional Approach and Panel Regression}

\author{
Zulfikar Mohamad Yamin Latuconsina ${ }^{1 *}$ \\ ${ }^{1}$ Dinas Perumahan, Kawasan Permukiman dan Cipta Karya Kabupaten Malang, \\ J1. Trunojoyo Kav. 6 Kepanjen; "Penulis korespondensi. $e$-mail: zul_latuconsina@ yahoo.co.id \\ (Diterima: 12 Mei 2017; Disetujui: 25 Juli 2017)
}

\begin{abstract}
Regionalization approach is a kind of approach to manage and to achieve the development goals based on the characteristics of a region. The development system of Malang Regency is conducted through regionalization approach which divided the area into six Development Areas (WP). Furthermore, the typology of development area in Malang Regency can be divided into three typology (urban, peri-urban and rural). This research aims to analyze factors that influence the human development index (HDI) of Malang Regency based on regionalization approach and panel regression. Data panel regression method was used in analyzing the data. The results of the research showed variables that have a positive and significant influence to the human development index in each typology of development areas of Malang Regency consisting of the number of health facilities, the number of nurse-midwife and the population density in typology I (urban); the ratio of school per students at primary school and the population density in typology II (peri-urban); and the number of nurse-midwife in typology III (rural).
\end{abstract}

Keywords: development area, human development index, typology, panel data regression

\begin{abstract}
ABSTRAK
Pendekatan perwilayahan merupakan salah satu pendekatan untuk mengelola dan mencapai tujuan pembangunan sesuai dengan karakteristik wilayah. Sistem pembangunan Kabupaten Malang dilaksanakan melalui pendekatan perwilayahan dimana Kabupaten Malang dibagi menjadi enam wilayah pengembangan (WP). Tipologi wilayah pengembangan di Kabupaten Malang terbagi menjadi tiga (perkotaan, peri-urban, dan perdesaan). Tujuan penelitian ini adalah menganalisis faktor-faktor yang mempengaruhi indeks pembangunan manusia (IPM) di Kabupaten Malang berbasis pendekatan perwilayahan dan regresi panel. Teknik analisis yang digunakan adalah analisis regresi panel data. Hasil penelitian menunjukkan variabel-variabel yang berpengaruh positif dan signifikan terhadap indeks pembangunan manusia pada tiap tipologi wilayah pengembangan Kabupaten Malang, diantaranya: faktor jumlah sarana kesehatan, jumlah perawat-bidan dan kepadatan penduduk pada tipologi I (urban); faktor rasio sekolah per siswa SD dan kepadatan penduduk pada tipologi II (peri-urban); dan faktor jumlah perawat-bidan pada tipologi III (rural).

Kata kunci: wilayah pengembangan, indeks pembangunan manusia, tipologi wilayah, regresi panel
\end{abstract}




\section{PENDAHULUAN}

Pembangunan menurut Rustiadi et al. (2011) dapat diartikan sebagai kegiatankegiatan yang dilakukan suatu negara/wilayah untuk mengembangkan kualitas hidup masyarakatnya. Pembangunan harus dipandang sebagai suatu proses di mana terdapat saling keterkaitan dan saling mempengaruhi antara faktor-faktor yang menyebabkan terjadinya perkembangan tersebut dapat diidentifikasi dan dianalisis dengan seksama sehingga diketahui runtutan peristiwa yang timbul yang akan mewujudkan peningkatan taraf kesejahteraan masyarakat dari satu tahap pembangunan ke tahap pembangunan berikutnya.

Pembangunan/pengembangan wilayah dapat dirumuskan sebagai rangkaian upaya untuk mewujudkan keterpaduan dalam penggunaan berbagai sumber daya, merekatkan dan menyeimbangkan pembangunan, meningkatkan keserasian antar kawasan, keterpaduan antar sektor pembangunan melalui proses penataan ruang dalam rangka pencapaian tujuan pembangunan yang berkelanjutan (Hariyanto dan Tukidi, 2007).

Pembangunan dapat dilakukan dengan dua pendekatan, yaitu pendekatan sektoral dan pendekatan regional (wilayah). Pendekatan sektoral memfokuskan perhatiannya pada sektor-sektor kegiatan yang ada di wilayah tersebut sedangkan pendekatan wilayah (regional) melihat pemanfaatan ruang serta interaksi-interaksi berbagai kegiatan dalam ruang suatu wilayah. Pendekatan wilayah ini memandang wilayah sebagai kumpulan dari bagian-bagian wilayah yang lebih kecil dengan potensi dan daya tarik serta daya dorong yang berbeda-beda yang mengharuskan mereka menjalin hubungan untuk mendapatkan manfaat yang sebesar-besarnya (Iryanto, 2006).

Pendekatan perwilayahan merupakan salah satu pendekatan untuk mengelola dan mencapai tujuan-tujuan pembangunan sesuai dengan karakteristik wilayah. Kebijakan perwilayahan digunakan untuk penerapan pengelolaan (manajemen) sumber daya yang memerlukan pendekatan yang berbeda-beda sesuai dengan perbedaan karakteristik secara spasial (Rustiadi et al., 2011).

Sistem pembangunan di Indonesia berbasis pendekatan wilayah dilaksanakan melalui sistem regionalisasi atau perwilayahan yaitu membagi wilayah ke dalam wilayah pembangunan/pengembangan (WP). Hal ini bertujuan lebih menjamin tercapainya pembangunan yang serasi dan seimbang, baik antar sektor di dalam suatu wilayah maupun antar wilayah (Nurhadi, 2012).

Wilayah pengembangan merupakan bagian-bagian wilayah yang diprioritaskan untuk dikembangkan berdasarkan karakteristik dan potensi yang dimiliki, sehingga diharapkan akan tercipta pusat-pusat pertumbuhan yang mampu memotivasi dan membangkitkan pertumbuhan wilayah itu sendiri dan wilayah sekitarnya (hinterland). Percepatan pengembangan wilayah melalui strategi wilayah pengembangan (WP) merupakan suatu upaya untuk pelaksanaan kebijakan pengembangan wilayah yang memungkinkan WP dapat berjalan sesuai dengan fungsi dan peranan yang sudah ditetapkan, sehingga memungkinkan terciptanya pola pengembangan wilayah yang lebih seimbang (Hariyanto, 2006).

Wilayah pengembangan bisa dikaitkan dengan pengembangan cluster dalam skala wilayah. Vuković dan Wei (2010) mengemukakan bahwa salah satu komponen penting dari daya saing daerah adalah pengembangan cluster. Daerah yang mengembangkan cluster hampir selalu lebih kompetitif dibandingkan dengan daerah lain karena ditandai dengan spesialisasi yang lebih besar, kapasitas informasi dan organisasi bisnis yang lebih baik, efek positif dari jaringan kewirausahaan dan lain-lain.

Kebijakan sistem perwilayahan di Kabupaten Malang ditetapkan menjadi 6 (enam) WP pada tahun 2010 sebagaimana tercantum dalam Rencana Tata Ruang dan Wilayah (RTRW) Kabupaten Malang. Pembagian WP ini disesuaikan dengan keadaan dan potensi masing-masing wilayah serta menjadi salah satu bahan pertimbangan agar keberhasilan 
pembangunan di Kabupaten Malang dapat tercapai.

Keberhasilan pembangunan suatu wilayah diukur dengan beberapa parameter, dan paling populer saat ini adalah Indeks Pembangunan Manusia (IPM) atau Human Development Indeks (HDI) (Maulana dan Bowo 2013). UNDP menyusun suatu indeks komposit yaitu IPM berdasarkan tiga indikator: angka harapan hidup pada waktu lahir (life expectancy at birth), angka melek huruf penduduk dewasa (adult literacy rate) dan rata- rata lama sekolah (mean years of schooling), dan kemampuan daya beli (purchasing power parity). Indikator angka harapan hidup mengukur kesehatan, indikator angka melek huruf penduduk dewasa dan rata-rata lama sekolah mengukur pendidikan dan terakhir indikator daya beli mengukur standar hidup (Bhakti et al., 2014; Ginting et al., 2008).

IPM merupakan ukuran untuk melihat dampak kinerja pembangunan wilayah yang mempunyai dimensi yang sangat luas, karena memperlihatkan kualitas penduduk suatu wilayah dalam hal harapan hidup, pendidikan dan standar hidup layak (Melliana dan Zain, 2013). IPM merupakan alat kebijakan (Spangenberg 2015) yang merupakan hasil komprehensif dari berbagai faktor (Niu et al., 2013). IPM hadir sebagai alat ukur yang mampu menggambarkan tingkat kesejahteraan secara menyeluruh karena dapat menggambarkan faktor ekonomi dan non-ekonomi (Aji et al., 2014).

Tujuan Pembangunan Milenium atau Millenium Development Goals (disingkat MDGs) merupakan paradigma pembangunan global yang disepakati secara internasional oleh 189 negara anggota Perserikatan BangsaBangsa (PBB) dalam Konferensi Tingkat Tinggi (KTT) Milenium PBB bulan September 2000 silam. Sebagai salah satu negara yang ikut menandatangani Deklarasi MDGs, Indonesia mempunyai komitmen untuk melaksanakan program-program MDGs sebagai bagian yang tak terpisahkan dari program pembangunan nasional baik jangka pendek, menengah dan panjang (Juhardi et al., 2011; Latifah, 2011).
MDGs menempatkan pembangunan manusia sebagai fokus utama pembangunan sehingga nilai IPM menjadi salah satu indikator keberhasilan suatu wilayah/negara dalam melaksanakan MDGs. IPM digunakan untuk menilai kualitas pembangunan manusia, baik dari sisi dampaknya terhadap kondisi fisik manusia (kesehatan dan kesejahteraan) maupun yang bersifat non-fisik (pendidikan).

Ditinjau dari olahan data Bappeda dan BPS Kabupaten Malang tahun 2007-2014 diketahui bahwa rata-rata capaian nilai IPM Kabupaten Malang sebesar 70.77. Hanya WP I Lingkar Kota Malang yang menunjukkan ratarata nilai IPM diatas Kabupaten Malang yaitu sebesar 72.78. WP lainnya menunjukkan ratarata nilai IPM dibawah Kabupaten Malang yaitu WP V Turen dan Dampit sebesar 69.91, WP IV Tumpang sebesar 69.53, WP II Kepanjen sebesar 69.44, WP III Ngantang sebesar 67.38 dan WP VI Sumbermanjing Wetan sebesar 67.23. Penelitian ini bertujuan menganalisis faktor-faktor yang mempengaruhi indeks pembangunan manusia (IPM) di Kabupaten Malang berbasis pendekatan perwilayahan dan regresi panel.

\section{METODOLOGI}

Penelitian dilaksanakan selama tujuh bulan yaitu dari bulan April sampai dengan Oktober 2016. Lokasi penelitian di Kabupaten Malang, Provinsi Jawa Timur yang memiliki luas wilayah $3,534.86 \mathrm{~km}^{2}$. Lokasi penelitian meliputi enam wilayah pengembangan (WP) yang terbagi ke dalam tiga tipologi, yaitu:

1. Tipologi I dengan ciri wilayah perkotaan yaitu WP I Lingkar Kota Malang (9 Kecamatan, yaitu: Dau, Karangploso, Lawang, Singosari, Pakisaji, Wagir, Tajinan, Bululawang dan Pakis) dengan luas wilayah $529.92 \mathrm{~km}^{2}$ atau $14.99 \%$ dari luas Kabupaten Malang. Jumlah penduduk pada tipologi I ini yaitu 898,538 jiwa (35.32\%) dengan tingkat kepadatan penduduk tertinggi dibandingkan dengan tipologi lainnya yaitu sebesar 1,696 jiwa $/ \mathrm{km}^{2}$. Angka IPM pada tipologi I menunjukkan rata-rata nilai IPM diatas 
Kabupaten Malang (70.77) yaitu sebesar 72.78 .

Tipologi II dengan ciri wilayah peri-urban meliputi WP II Kepanjen (10 Kecamatan, yaitu: Kepanjen, Wonosari, Ngajum, Kromengan, Pagak, Sumberpucung, Kalipare, Donomulyo, Gondanglegi dan Pagelaran), WP IV Tumpang (4 Kecamatan, yaitu: Tumpang,

2. Poncokusumo, Wajak dan Jabung) serta WP V Turen dan Dampit (4 Kecamatan, yaitu: Turen, Dampit, Tirtoyudo dan Ampelgading) dengan luas wilayah 2,121.68 $\mathrm{km}^{2}$ atau $60.02 \%$ dari luas Kabupaten Malang. Sebagian besar penduduk Kabupaten Malang berada pada tipologi II yaitu sebanyak 1,278,810 jiwa (50.26\%) dengan tingkat kepadatan penduduk sebesar $603 \mathrm{jiwa} / \mathrm{km}^{2}$. Angka IPM pada tipologi II menunjukkan rata-rata nilai IPM dibawah Kabupaten Malang (70.77) yaitu sebesar 69.62.

3. Tipologi III dengan ciri wilayah perdesaan meliputi WP III Ngantang (3 Kecamatan, yaitu: Ngantang, Pujon dan Kasembon) dan WP VI Sumbermanjing Wetan (3 Kecamatan, yaitu: Sumbermanjing Wetan, Gedangan dan Bantur) dengan luas wilayah $883.26 \mathrm{~km}^{2}$ atau $24.99 \%$ dari luas Kabupaten Malang. Jumlah penduduk pada tipologi III ini yaitu 366,967 jiwa (14.42\%) dengan tingkat kepadatan penduduk terendah dibandingkan dengan tipologi lainnya yang hanya sebesar $415 \mathrm{jiwa} / \mathrm{km}^{2}$. Angka IPM pada tipologi II menunjukkan rata-rata nilai IPM dibawah Kabupaten Malang (70.77) yaitu sebesar 67.30.

Jenis dan sumber data yang digunakan dalam penelitian ini menggunakan data sekunder, yaitu:

> Data Indeks Pembangunan Manusia (IPM) yang diperoleh dan diolah dari Bappeda Kabupaten Malang.

Data kepadatan penduduk, rasio rumah tangga pra sejahtera per penduduk, jumlah dokter, perawat-bidan dan tenaga kesehatan, jumlah fasililitas kesehatan dan pendidikan, jumlah guru dan murid, rasio guru per siswa, rasio sekolah per siswa dan rasio perawatbidan per puskesmas yang diperoleh dan diolah dari BPS Kabupaten Malang berupa data Kabupaten Malang dalam Angka.

Analisis yang digunakan dalam penelitian ini adalah analisis regresi panel data menggunakan software statistik EViews 6. Bentuk data yang digunakan berupa data panel yaitu penggabungan antara data lintas waktu (times series) dan data lintas individu (cross section). Data times series merupakan data untuk melihat perkembangan dari waktu ke waktu, data yang diambil dari tahun 2010 sampai 2014. Data cross section merupakan data yang diambil dari kecamatan-kecamatan yang ada pada masing-masing tipologi WP Kabupaten Malang pada rentang tahun tersebut.

Pada panel data, masing-masing seri menghasilkan informasi dan hasil yang tidak dimiliki oleh seri lain. Kombinasi keduanya akan sangat mengarah pada hasil yang lebih akurat dan andal dibanding satu seri saja. Data panel berisi berbagai kelebihan seperti mengendalikan korelasi serial dan heterogenitas individu, meningkatkan derajat kebebasan dan keandalannya (Shuai et al., 2017). Kelebihan lainnya yaitu yaitu bersifat robust terhadap beberapa tipe pelanggaran asumsi Gauss Markov, yakni heteroskedastisitas dan normalitas, serta dimungkinkannya estimasi masing-masing karakteristik individu maupun karakteristik waktu (periode) secara terpisah.

Sebelum melakukan analisis maka ditentukan terlebih dahulu variabel terikat (dependent variable) yaitu indeks pembangunan manusia (IPM) dan variabel bebas (independent variables) yang diduga berpengaruh terhadap IPM. Beberapa pilihan variabel bebas yang mewakili (proxy) masing-masing aspek IPM sesuai teori, yaitu:

1. Aspek standar hidup layak yaitu rasio rumah tangga pra sejahtera terhadap penduduk.

2. Aspek kesehatan yaitu jumlah sarana kesehatan, jumlah tenaga kesehatan, jumlah perawat-bidan, jumlah puskesmas, jumlah dokter, rasio tenaga kesehatan terhadap puskesmas, rasio perawat-bidan terhadap jumlah penduduk. 
3. Aspek pendidikan yaitu jumlah fasilitas pendidikan total (SD, SMP dan SMA), jumlah fasilitas pendidikan (SD/SMP/SMA), jumlah guru (SD/SMP/SMA), Jumlah murid (SD/SMP/SMA), rasio guru terhadap siswa (SD/SMP/SMA), rasio sekolah terhadap siswa (SD, SMP, SMA).

1. Aspek kependudukan yaitu kepadatan penduduk. Kepadatan penduduk menjadi variabel bebas untuk menjadi variabel kontrol, karena pemerintah daerah cenderung untuk melakukan berbagai program pembangunan yang berkaitan dengan percepatan peningkatan IPM pada daerah dengan tingkat kepadatan penduduk yang tinggi. Sebaliknya daerah yang padat penduduk akan mengakibatkan pemenuhan jasa kesehatan dan pendidikan yang kurang baik dan tidak merata, sehingga dapat berdampak negatif terhadap pencapaian IPM.

\section{Metode Estimasi Model Regresi}

Dalam melakukan estimasi dengan model regresi panel data terdapat 3 pendekatan yang sering digunakan, yaitu: metode Pooled Ordinary Least Squared (PLS), Fixed Effect Model (FEM) dan Random Effect Model (REM).

\section{Pooled Ordinary Least Squared (PLS)}

Metode ini dikenal juga sebagai Common Effect Model (CEM). Pada metode ini, model mengasumsikan bahwa data gabungan yang ada, menunjukan kondisi sesungguhnya dimana nilai intersep dari masing-masing variabel adalah sama dan slope koefisien dari variabel-variabel yang digunakan adalah identik untuk semua unit cross section. Kelemahan dalam model PLS ini yaitu adanya ketidaksesuaian model dengan keadaan yang sesungguhnya, dimana kondisi tiap objek saling berbeda, bahkan satu objek pada suatu waktu akan sangat berbeda dengan kondisi objek tersebut pada waktu yang lain (Winarno, 2015).

Widarjono (2007) dalam Melliana dan Zain (2013) mengatakan bahwa pada model PLS/CEM $\alpha$ konstan atau sama di setiap individu maupun setiap periode. PLS/CEM dinyatakan dalam model sebagai berikut:

$$
\mathrm{Y}_{i t}=\alpha+\beta^{\prime} \mathrm{X}_{i t}+\mathrm{e}_{i t}
$$

\section{Fixed Effect Model (FEM)}

Pendekatan FEM menetapkan bahwa $\alpha$ adalah sebagai kelompok yang spesifik/berbeda dalam constant term pada model regresinya. Formulasi yang biasa dipakai dalam model mengasumsikan bahwa perbedaan antar unit dapat dilihat dalam perbedaan constant term. FEM disini mengasumsikan bahwa tidak ada time spesific effects dan hanya memfokuskan pada individual spesific effects dengan model sebagai berikut (Hsiao, 2003 dalam Melliana dan Zain, 2013):

$$
\mathrm{Y}_{i t}=\alpha_{i}+\beta^{\prime} \mathrm{X}_{i t}+\mathrm{e}_{i t}
$$

Indeks $i$ pada intersep $\left(\alpha_{i}\right)$ menunjukkan bahwa intersep dari masing-masing individu berbeda, namun intersep untuk unit time series tetap (konstan).

\section{Random Effect Model (REM)}

Dalam metode REM perbedaan karakteristik individu dan waktu diakomodasikan pada error dari model. Teknik ini juga memperhitungkan bahwa error mungkin berkorelasi sepanjang time series dan cross section (Nachrowi dan Usman, 2006).

$$
\mathrm{Y}_{\mathrm{it}}=\alpha_{i t}+\beta^{\prime} \mathrm{X}_{i t}+\mathrm{e}_{i t}
$$

Dengan asumsi $\alpha_{i t}$ adalah variabel random dengan $\alpha_{0}$ sehingga intersep tiap unit adalah (Melliana dan Zain, 2013):

$$
\alpha_{i}=\alpha_{0}+\varepsilon_{\mathrm{i}}
$$

dimana $\mathrm{i}=1,2, \ldots, \mathrm{N}, \quad$ sehingga modelnya menjadi:

$$
\begin{aligned}
& \mathrm{Y}_{\mathrm{it}}=\alpha_{0}+\beta^{\prime} \mathrm{X}_{i t}+\varepsilon_{\mathrm{i}}+\mathrm{e}_{i t} \\
& \mathrm{Y}_{\mathrm{it}}=\alpha_{0}+\beta^{\prime} \mathrm{X}_{i t}+\mathrm{w}_{i t}
\end{aligned}
$$


Suku error gabungan $\mathrm{w}_{i t}$ terdiri atas komponen error cross section $\left(\varepsilon_{\mathrm{i}}\right)$ dan komponen error time series $\left(\mathrm{e}_{i t}\right)$.

Karena Validitas korelasi antara $\mathrm{X}_{i t}$ dan $\alpha \mathrm{i}$ dalam karya empiris, Pendekatan fixed effects mendapat perhatian lebih dari pada pendekatan Random Effect (Su et al., 2016).

\section{Uji Pemilihan Model}

Dari ketiga pendekatan diatas, selanjutnya dilakukan pengujian untuk memilih model data panel yang paling tepat dan sesuai. Uji pemilihan model pada model data panel dapat dilakukan dengan hausman test dan chow test.

\section{Hausman test}

Hausman (1978) dalam Pratowo (2012) mengembangkan suatu uji statistik untuk memilih apakah menggunakan FEM atau REM. Uji Hausman menggunakan statistik uji $\mathrm{H}$ yang mengikuti distribusi chi-square dengan derajat bebas (db) sebesar jumlah variabel independen. Kesimpulan yang diambil: jika $\mathrm{H}_{0}$ ditolak, maka model regresi FEM lebih baik daripada REM. Tetapi jika $\mathrm{H}_{0}$ diterima, berarti model regresi REM lebih baik daripada FEM.

Selain itu dasar penolakan $\mathrm{H}_{0}$ bisa juga dilihat dari nilai $p$-value nya. Jika $p$-value lebih kecil dari 5\% maka dapat disimpulkan bahwa model FEM lebih baik dibandingkan dengan model REM. Hausman test dilakukan dengan hipotesis sebagai berikut:

$$
\begin{aligned}
& \mathrm{H}_{0} \text { : Model random effect } \\
& \mathrm{H}_{1} \text { : Model fixed effect }
\end{aligned}
$$

\section{Chow test}

Menurut Widarjono (2007) dalam Pratowo (2012), uji Chow merupakan uji perbedaan dua model regresi untuk menentukan model yang paling baik, antara FEM atau CEM/PLS dengan menggunakan statistik uji F. Chow test dilakukan dengan hipotesis sebagai berikut:

\section{$\mathrm{H}_{0}$ : Model pooled least square$$
\mathrm{H}_{1} \text { : Model fixed effect }
$$

Jika nilai F-stat lebih besar daripada F-tabel, maka cukup bukti untuk menolak hipotesis nol sehingga model yang digunakan adalah model FEM, dan sebaliknya.

\section{Uji Pelanggaran Asumsi}

Model regresi berganda yang diestimasi melalui Ordinary Least Squares (OLS) harus dapat memenuhi asumsi kriteria BLUE (Best Linear Unbiased Estimatori) yang dikenal dengan nama teorema Gauss-Markov. Estimator bersifat best yang berarti memiliki varians terkecil/minimum dibandingkan dengan parameter yang diperoleh melalui metode linier lain (Non OLS), estimator juga bersifat linier terhadap variabel dependen serta bersifat unbiased yang berarti nilai estimator mendekati nilai populasi.

Ada beberapa permasalahan yang bisa menyebabkan sebuah estimator tidak dapat memenuhi asumsi kriteria BLUE, yaitu:

\section{a. Normalitas}

Winarno (2015) menyatakan bahwa salah satu asumsi dalam analisis statistika adalah data berdistribusi normal. Cara mengujinya dengan alat analisis dan Eviews menggunakan dua cara, yaitu dengan histogram dan uji Jarque-Bera. Sebenarnya normalitas data dapat dilihat dari gambar histogram, namun polanya tidak mengikuti bentuk kurva normal sehingga sulit disimpulkan. Lebih mudah bila melihat koefisien Jarque-Bera dan probabilitasnya. Kedua angka ini bersifat saling mendukung.

- Bila nilai Jarque-Bera tidak signifikan (lebih kecil dari 2) maka data berdistribusi normal.

- Bila nilai probabilitas lebih besar dari $5 \%$, maka data berdistribusi normal (hipotesis nolnya adalah data berdistribusi normal).

\section{b. Multikolinearitas}

Winarno (2015) menjelaskan mengenai multikolinearitas yaitu adanya hubungan linier antara variabel independen. Terjadinya multikolinearitas ditunjukkan dengan beberapa indikator, yaitu:

1. Nilai $R$-square $\left(\mathrm{R}^{2}\right)$ tinggi, tetapi variabel independen banyak yang tidak signifikan. 
2. Menghitung koefisien korelasi antar variabel independen. Apabila koefisiennya rendah, maka tidak terdapat multikolinearitas.

3. Melakukan regresi auxiliary untuk mengetahui hubungan antara dua (atau lebih) variabel independen yang secara bersama-sama mempengaruhi satu variabel independen yang lain.

Beberapa alternatif yang dapat dilakukan untuk mengatasi masalah multikolinearitas adalah membiarkan saja model kita mengandung multikolinearitas karena estimatornya masih dapat bersifat BLUE, menambah data baru, menghilangkan salah satu variabel independen, terutama yang memiliki hubungan linier yang kuat dengan variabel lain dam transformasi salah satu (atau beberapa) variabel termasuk misalnya dengan melakukan diferensi.

\section{c. Heteroskedastisitas}

Salah satu asumsi dasar dari metode regresi linier adalah varians tiap unsur error adalah suatu angka konstan yang sama atau homogen. Heteroskedastisitas terjadi ketika varians tiap unsur error tidak konstan. Winarno (2015) menyatakan bahwa heteroskedastisitas dapat menyebabkan:

1. Estimator metode kuadrat terkecil tidak mempunyai varian yang minimum (tidak lagi BEST), sehingga hanya memenuhi karakteristik LUE (Linear Unbiased Estimator). Meskipun demikian, estimator metode kuadrat terkecil masih bersifat linier dan tidak bias.

2. Perhitungan standard error tidak dapat lagi dipercaya kebenarannya karena varian tidak minimum. Varian yang tidak minimum mengakibatkan estimasi regresi tidak efisien.

3. Uji hipotesis yang didasarkan pada uji $\mathrm{t}$ dan uji $\mathrm{F}$ tidak dapat lagi dipercaya, karena standard error-nya tidak dapat dipercaya.

Salah satu teknik pendugaan yang cocok jika terjadi heteroskedastisitas jika ragam sisaan diketahui adalah menggunakan metode kuadrat terkecil terboboti (WLS, weighted least squares) yang merupakan kasus khusus dari teknik ekonometrika yang lebih umum, yang disebut dengan GLS (generalized least squares).

Uji heteroskedastisitas dapat menggunakan metode GLS Weights Crosssection weight yang tersedia dalam program EViews di mana jika terdapat masalah heteroskedastisitas, nilai Sum squared residu Weighted Statistic akan lebih kecil dibandingkan dengan nilai Sum squared resid Unweighted Statistic.

\section{d. Autokorelasi}

Winarno (2015) menyatakan bahwa autokorelasi adalah hubungan antara residual atau observasi dengan residual observasi lainnya. Data yang mengandung autokorelasi maka estimator yang didapatkan masih linier, tidak bias tetapi tidak mempunyai varian yang minimum (no longer best). Dengan demikian, seperti halnya pengaruh heteroskedastisitas, autokorelasi juga akan menyebabkan estimator hanya bersifat LUE, tidak lagi BLUE. Salah satu cara memeriksa ada tidaknya autokorelasi adalah dengan melakukan uji Durbin-Watson (DW).

\section{Uji Statistik (Test of Goodness of Fit)}

Evaluasi model estimasi berdasarkan kriteria statistik dilakukan dengan melakukan beberapa pengujian yang antara lain sebagai berikut:

a. Koefisien Determinasi ( $R$-square)

Winarno (2015) menyatakan bahwa model yang sudah dianalisis, harus diuji kualitasnya dengan menghitung koefisien determinasi yang dilambangkan dengan $\mathrm{R}^{2}$ ( $R$-square). Nilai $\mathrm{R}^{2}$ selalu berada di antara 0 dan 1 . Semakin besar nilai $\mathrm{R}^{2}$, semakin baik kualitas model, karena semakin dapat menjelaskan hubungan antara variabel dependen dan independen.

b. Uji F-Statistik

Uji F-statistik ini adalah pengujian yang bertujuan mengetahui pengaruh semua variabel independen secara bersama-sama 
terhadap variabel dependen. Statistik uji F mengikuti distribusi $\mathrm{F}$ dengan derajat bebas sebanyak (k-1) untuk numerator dan (n-k) untuk denumerator, dimana $\mathrm{k}$ merupakan banyaknya parameter termasuk intersep/ konstanta, sedangkan $\mathrm{n}$ adalah banyaknya observasi (Widarjono, 2007 dalam Pratowo, 2012).

Nilai F-Statistik yang besar lebih baik dibandingkan dengan nilai F-Statistik yang rendah. Nilai Prob (F-Statistik) merupakan tingkat signifikansi marginal dari F-Statistik. Dengan menggunakan hipotesis pengujian sebagai berikut:

$$
\begin{aligned}
& \mathrm{H}_{0}: \beta_{1}=\beta_{2}=\ldots=\beta_{\mathrm{k}}=0 \\
& \mathrm{H}_{1}: \text { minimal ada salah satu } \beta_{\mathrm{j}} \\
& \text { yang tidak sama dengan nol }
\end{aligned}
$$

Tolak $\mathrm{H}_{0}$ jika F-Statistik > F $\alpha$ (k-1, nt-n-k) atau Prob (F-Statistik) < $\alpha$. Jika $\mathrm{H}_{0}$ ditolak, maka artinya dengan tingkat keyakinan 1$\alpha$ kita dapat menyimpulkan bahwa variabel independen yang digunakan di dalam model secara bersama-sama signifikan mempengaruhi variabel dependen.

c. Uji t-Statistik

Uji t-Statistik digunakan untuk mengetahui apakah variabel-variabel independen secara parsial berpengaruh signifikan terhadap variabel dependen. Dengan menggunakan hipotesis pengujian sebagai berikut:

$$
\begin{aligned}
& \mathrm{H}_{0}: \beta \mathrm{j}=0 \\
& \mathrm{H}_{1}: \beta \mathrm{j} \neq 0
\end{aligned}
$$

Tolak $\mathrm{H}_{0}$ jika t-Statistik $>\mathrm{t}_{\alpha / 2}(\mathrm{NT}-\mathrm{K}-1)$ atau tStatistik $<\alpha$. Jika Ho ditolak, maka artinya dengan tingkat keyakinan $1-\alpha$ kita dapat menyimpulkan bahwa variabel independen ke-i secara parsial signifikan mempengaruhi variabel dependen.

\section{HASIL DAN PEMBAHASAN}

Dari beberapa variabel tersebut diatas, dipilih kombinasi variabel yang menghasilkan model regresi terbaik untuk masing-masing tipologi, yaitu:

- Tipologi I:

$$
\begin{gathered}
\mathrm{Y}_{i t}=\alpha_{i t}+\beta_{1} \mathrm{X}_{1 i t}+\beta_{2} \mathrm{X}_{2 i t}+\beta_{3} \mathrm{X}_{3 i t}+\beta_{4} \mathrm{X}_{4 i t}+ \\
\beta_{5} \mathrm{X}_{5 i t}+\mathrm{e}_{i t}
\end{gathered}
$$

dimana:

$\mathrm{Y}_{i t}=$ indeks pembangunan manusia $(\mathrm{IPM}) \mathrm{di}$ kecamatan ke- $i$ tahun ke- $t$

$\mathrm{X}_{1}=$ jumlah fasilitas kesehatan (unit)

$\mathrm{X}_{2}=$ kepadatan penduduk (jiwa $/ \mathrm{km}^{2}$ )

$\mathrm{X}_{3}=$ rasio rumah tangga pra sejahtera terhadap penduduk (\%)

$\mathrm{X}_{4}=$ jumlah fasilitas SMP (unit)

$\mathrm{X}_{5}=$ jumlah perawat-bidan (jiwa)

$\alpha_{i t}=$ konstanta

$\beta \mathbf{i}=$ koefisien regresi peubah ke- $i$

$i=1,2, \ldots ., 9$ (data cross section 9 kecamatan pada tipologi I)

$t=$ deret waktu (data time series tahun 20102014)

$e_{i t}=$ komponen Error $/$ Galat model di waktu $t$ untuk cross section ke- $i$

- Tipologi II:

$\mathrm{Y}_{i t}=\alpha_{i t}+\beta_{1} \mathrm{X}_{1 i t}+\beta_{2} \mathrm{X}_{2 i t}+\beta_{3} \mathrm{X}_{3 i t}+\beta_{4} \mathrm{X}_{4 i t}+\mathrm{e}_{i t}$ dimana:

$\mathrm{Y}_{i t}=$ indeks pembangunan manusia $(\mathrm{IPM}) \mathrm{di}$ kecamatan ke- $i$ tahun ke- $t$

$\mathrm{X}_{1}=$ rasio sekolah terhadap siswa SD (\%)

$\mathrm{X}_{2}=$ kepadatan penduduk (jiwa $/ \mathrm{km}^{2}$ )

$\mathrm{X}_{3}=$ rasio rumah tangga pra sejahtera terhadap penduduk $(\%)$

$\mathrm{X}_{4}=$ jumlah perawat-bidan (jiwa)

$\alpha_{i t}=$ konstanta

$\beta \mathrm{i}=$ koefisien regresi peubah ke- $i$

$i=1,2, \ldots ., 18$ (data cross section 18 kecamatan pada tipologi II)

$t=$ deret waktu (data time series tahun 20102014)

$\mathrm{e}_{i t}=$ komponen Error $/$ Galat model di waktu $t$ untuk cross section ke- $i$

- Tipologi III:

$\mathrm{Y}_{i t}=\alpha_{i t}+\beta_{1} \mathrm{X}_{1 i t}+\beta_{2} \mathrm{X}_{2 i t}+\beta_{3} \mathrm{X}_{3 i t}+\beta_{4} \mathrm{X}_{4 i t}+\mathrm{e}_{i t}$ dimana:

$\mathrm{Y}_{i t}=$ indeks pembangunan manusia $(\mathrm{IPM}) \mathrm{di}$ kecamatan ke- $i$ tahun ke- $t$

$\mathrm{X}_{1}=$ rasio guru terhadap siswa SMA (\%) 
$\mathrm{X}_{2}=$ jumlah fasilitas kesehatan (unit)

$\mathrm{X}_{3}=$ kepadatan penduduk (jiwa $/ \mathrm{km}^{2}$ )

$\mathrm{X}_{4}=$ jumlah perawat-bidan (jiwa)

$\alpha_{i t}=$ konstanta

$\beta \mathrm{i}=$ koefisien regresi peubah ke- $i$

$i=1,2, \ldots, 6$ (data cross section 6 kecamatan pada tipologi III)

$t=$ deret waktu (data time series tahun 20102014)

$\mathrm{e}_{i t}=$ komponen Error/Galat model di waktu $t$ untuk cross section ke- $i$

Beberapa tahapan yang dilakukan dalam analisis panel data indeks pembangunan manusia pada 3 (tiga) tipologi wilayah pengembangan meliputi hasil uji pemilihan model, hasil uji pelanggaran asumsi, hasil uji statistik dan interpretasi model.

\section{Hasil Uji Pemilihan Model}

Pada metode panel data terdapat beberapa macam model ekonometrika yaitu Pooled Least Square (PLS), Fixed Effect Model (FEM), dan Random Effect Model (REM). Untuk mendapatkan hasil estimasi yang sesuai maka perlu dilakukan pemilihan model regresi terbaik. Proses ini dilakukan dengan dua tahap yaitu uji Hausman untuk menentukan apakah REM atau FEM dan uji Chow untuk menentukan apakah FEM atau PLS sebagaimana Tabel 1.

Tabel 1. Rekapitulasi hasil uji Hausman dan uji Chow

\begin{tabular}{|c|c|c|c|}
\hline \multirow{2}{*}{$\begin{array}{c}\text { Uji model } \\
\text { terbaik }\end{array}$} & \multicolumn{3}{|c|}{ Probabilitas $C h i-S q$} \\
\hline & Tipologi & $\begin{array}{c}\text { Tipologi } \\
2\end{array}$ & $\begin{array}{c}\text { Tipologi } \\
3\end{array}$ \\
\hline Probabilitas & & & \\
\hline Pijibabisitas & 0.0045 & 0.0005 & 0.0353 \\
\hline Ü̈Chow & 0.0003 & 0.0000 & 0.0238 \\
\hline
\end{tabular}

Pada Tabel 1 menunjukkan nilai probabilitas ( $p$-value) dari uji Hausman dan uji Chow. Nilai probabilitas uji Hausman untuk tipologi I, II dan III berturut-turut sebesar $0.0045,0.0005$ dan 0.0353 dimana nilai tersebut lebih kecil dari taraf nyata $(\alpha)$ sebesar 5\% (0.05) yang berarti menolak hipotesis untuk menggunakan model REM dan menerima hipotesis untuk menggunakan model FEM. Nilai probabilitas uji Chow untuk tipologi I, II dan III berturut-turut sebesar $0.0003,0.0000$ dan 0.0238 yang nilainya lebih kecil dari taraf nyata $(\alpha)$ sebesar $5 \%(0.05)$ yang berarti menolak hipotesis untuk menggunakan model PLS dan menerima hipotesis untuk menerima model FEM. Hasil uji Hausman dan uji Chow menyimpulkan bahwa metode estimasi yang sesuai untuk semua tipologi adalah FEM.

\section{Hasil Uji Pelanggaran Asumsi}

Uji pelanggaran asumsi dilakukan untuk membuktikan bahwa asumsi-asumsi yang diperlukan untuk menggunakan metode Least Squares terpenuhi serta menjamin bahwa estimator yang dihasilkan bersifat Best Linier Unbiased Estimator (BLUE). Hal tersebut perlu dilakukan agar hasil dari pengujian hipotesis berdasarkan model analisis tidak bias (Widarjono, 2007 dalam Rustariyuni, 2014). Uji pelanggaran asumsi yang meliputi uji normalitas, uji multikolinearitas, uji heteroskedastisitas dan uji autokorelasi.

\section{Uji Normalitas}

Uji normalitas dilakukan untuk memeriksa apakah error term mendekati distribusi normal atau tidak. Jika asumsi ini tidak terpenuhi, maka prosedur pengujian menggunakan t-statistik menjadi tidak sah. Uji normalitas error term dapat dilakukan dengan menggunakan uji Jarque-Bera (JB). Uji $J B$ dalam software EViews didapat dari histogram normality sebagaimana Gambar 1. Tipologi I

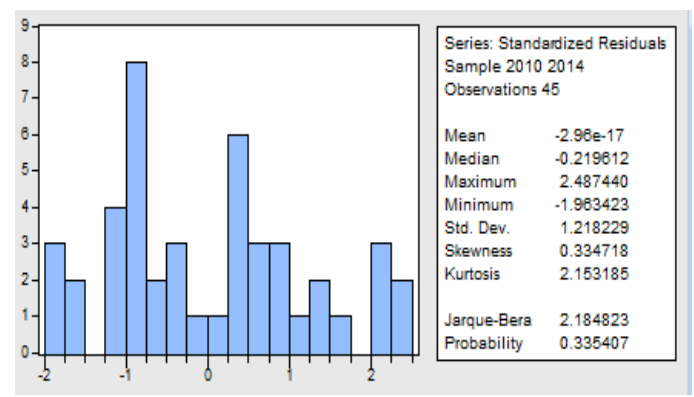


Tipologi II

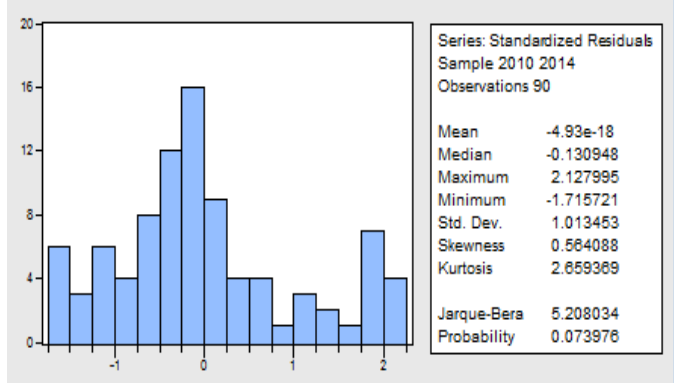

Tipologi III

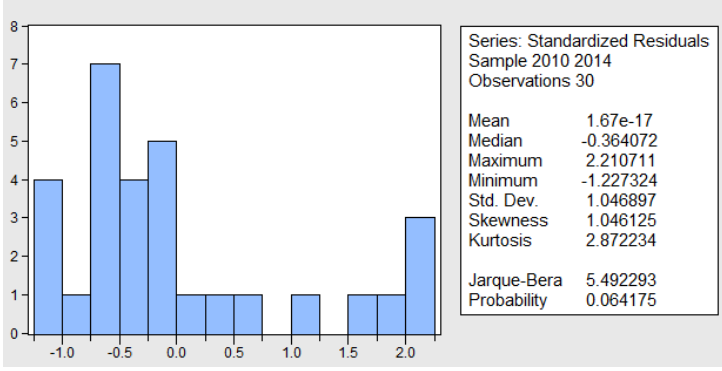

Gambar 1. Hasil uji Jarque-Bera (JB)

Sumber: Hasil pengolahan dengan EViews 6.0

Pada Gambar 1 menunjukkan bahwa nilai probabilitas Jarque-Bera untuk tipologi I, II dan III berturut-turut sebesar sebesar 0.335, 0.074 dan 0.064 yang lebih besar dari taraf nyata $(\alpha)$ sebesar $5 \%(0.05)$. Hal ini berarti error term terdistribusi dengan normal, sehingga pengujian menggunakan t-statistik telah sah.

\section{Uji Multikolinearitas}

Uji multikolinearitas dilakukan dengan melihat nilai perhitungan koefisien korelasi antar variabel bebas (independent variables) pada tiap-tiap tipologi sebagaimana Tabel 2. Model yang dipilih harus terbebas dari multikolinearitas yaitu apabila nilai koefisien korelasinya lebih rendah dari 0.80 sehingga dapat dikatakan bahwa tidak ada korelasi tinggi antara variabel bebas.

Hasil penghitungan nilai koefisien korelasi sebagaimana Tabel 2 menunjukkan bahwa korelasi antar variabel bebas pada ketiga tipologi wilayah pengembangan cukup rendah, hal ini terlihat dari koefisien korelasinya yang tidak melebihi 0.80 . Kesimpulan yang dapat diambil adalah tidak terjadi multikolinearitas sehingga kriteria bebas multikolinearitas terpenuhi dalam model estimasi ini. Penggunaan panel data sendiri dapat mengabaikan pelanggaran asumsi multikolinearitas. Hal ini karena penggabungan data cross section dan time series dapat mengurangi kolinearitas.

Tabel 2. Matriks korelasi antar variabel bebas pada tiap-tiap tipologi

- Tipologi I

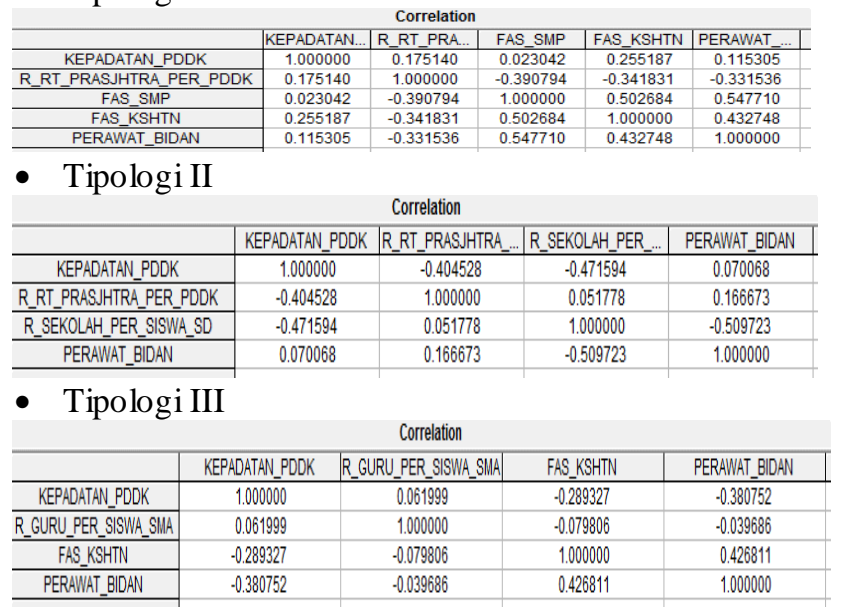

Sumber: Hasil pengolahan dengan EViews 6.0

\section{Uji Heteroskedastisitas}

Heteroskedastisitas dapat diketahui dengan melakukan GLS Weight Cross-Section Weight, yaitu dengan membandingkan Sum Square Resid pada Weighted Statistics dengan Sum Squared Resid Unweighted Statistic. Jika Sum Square Resid pada Weighted Statistic lebih kecil dibandingkan dengan Sum Square Resid Unweighted Statistics maka terjadi heteroskedastisitas.

Hasil uji yang dilakukan menunjukkan nilai Sum Square Resid Weighted untuk tipologi I, II dan III berturut-turut sebesar 65.29, 91.41 dan 31.78. Nilai ini lebih kecil dibandingkan dengan nilai Sum Square Resid Unweighted untuk tipologi I, II dan III berturut-turut sebesar 75.51, 95.93 dan 36.61. Kesimpulan yang diambil bahwa model estimasi terindikasi pelanggaran asumsi heteroskedastisitas dimana varians tiap unsur error tidak konstan.

Untuk menghilangkan adanya heteroskedastisitas maka model harus diperlakukan dengan cara Cross Section Weight. Model dalam penelitian ini pada ketiga tipologi menggunakan hasil estimasi Fixed Effect Model dengan metode 
pembobotan GLS Weight Cross-Section Weight sehingga masalah heteroskedastisitas langsung dapat terkoreksi dan model telah terbebas dari masalah heteroskedastisitas.

\section{Uji Autokorelasi}

Pengujian untuk mendeteksi autokorelasi dapat dilakukan dengan melihat nilai Durbin-Watson Statistic pada model dan membandingkannya dengan nilai DW-Tabel. Dengan mengetahui bahwa jumlah cross section untuk tipologi I, II dan III berturutturut sebesar 9, 18 dan 6, jumlah time series untuk semua tipologi sama yaitu sebesar 5, jumlah observasi untuk tipologi I, II dan III sebesar 45, 90 dan 30, jumlah variabel bebas untuk tipologi I, II dan III sebesar 5, 4 dan 4 dan a sebesar 5\% maka diperoleh nilai Durbin-Watson tabel untuk tipologi I: nilai $\mathrm{D}_{\mathrm{L}}$ sebesar 1.2874 dan $\mathrm{D}_{\mathrm{U}}$ sebesar 1.7762; tipologi II: nilai $\mathrm{D}_{\mathrm{L}}$ sebesar 1.5656 dan $\mathrm{D}_{\mathrm{U}}$ sebesar 1.7508; dan tipologi III: nilai $\mathrm{D}_{\mathrm{L}}$ sebesar 1.1426 dan $\mathrm{D}_{\mathrm{U}}$ sebesar 1.7386 sehingga diperoleh selang pengambilan keputusan seperti pada Gambar 2.

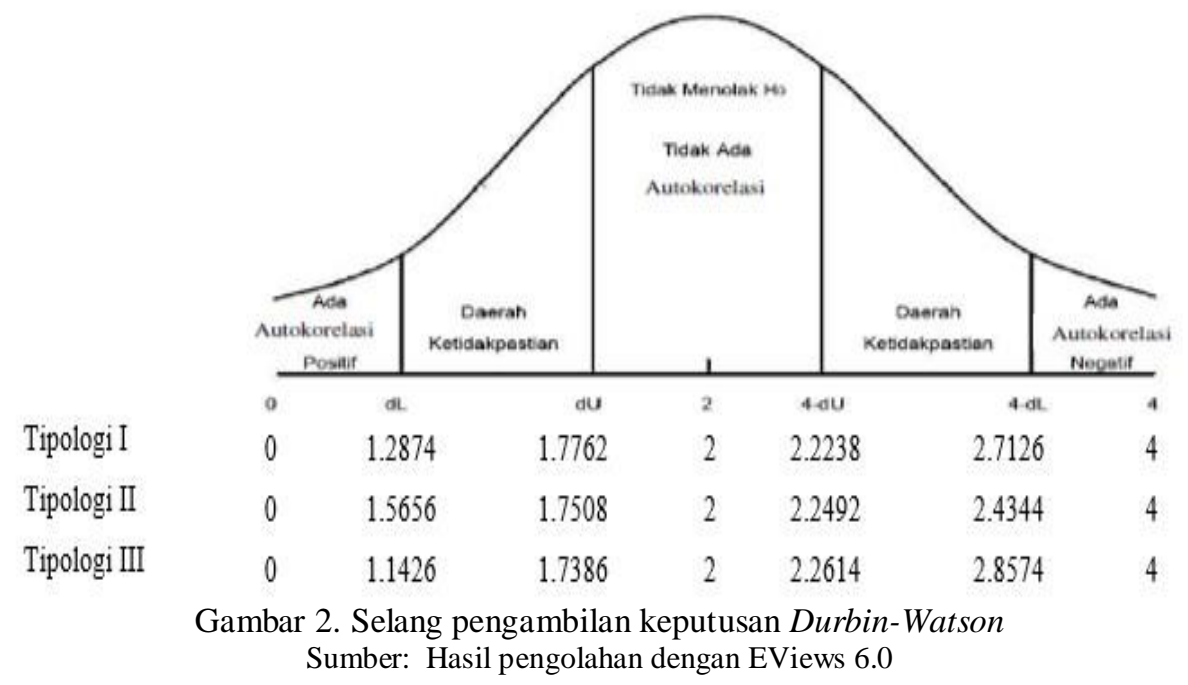

Berdasarkan hasil estimasi model (Fixed Effect Model dengan metode pembobotan GLS Weight Cross-Section Weight) didapatkan nilai statistika Durbin-Watson untuk tipologi I, II dan III berturut-turut sebesar 1.9137, 2.2909 dan 2.0302. Nilai untuk tipologi I dan tipologi III berada pada daerah tidak ada autokorelasi yaitu pada batasan $1.7762<\mathrm{DW}<2.2238$ untuk tipologi I dan $1.7386<$ DW $<2.2614$ untuk tipologi III, sedangkan nilai tipologi II berada pada batasan $2.2492<\mathrm{DW}<2.4344$ yaitu daerah ketidakpastian. Metode fixed effect sebenarnya tidak membutuhkan asumsi terbebasnya model dari serial korelasi, maka uji tentang autokorelasi dapat diabaikan (Nachrowi dan Usman 2006).

\section{Hasil Uji Statistik}

Berdasarkan hasil estimasi model didapatkan nilai koefisien determinasi ( $R$ square) untuk tipologi I, II dan III berturut-turut sebesar $0.8934,0.8817$ dan 0.8157 . Nilai tersebut berarti bahwa $89,34 \%, 88,17 \%$ dan $81,57 \%$ keragaman variabel bebas pada tipologi I, II dan III mampu menjelaskan variasi/keragaman variabel terikatindeks pembangunan manusia (IPM) pada tiap-tiap tipologi wilayah pengembangan Kabupaten Malang selama jangka waktu penelitian, sedangkan sisanya dijelaskan oleh variabel lain yang tidak termasuk dalam model estimasi.

Apabila dilihat dari nilai probabilitas F-statistik pada ketiga model tipologi yaitu sama dengan 0.000 yang signifikan pada tingkat keyakinan $95 \%$ atau $\alpha=5 \%$. Nilai tersebut 
berarti bahwa variabel bebas yang disertakan dalam model estimasi pada tiap-tiap tipologi secara bersama-sama atau serentak mampu menjelaskan variabel terikat indeks pembangunan manusia (IPM) pada tiap-tiap tipologi wilayah pengembangan Kabupaten Malang.

Dalam menganalisis uji $t$ dapat diinterpretasikan menggunakan nilai probabilitas t-statistik yang diharapkan dapat mendekati nilai nol. Apabila nilai probabilitasnya dibawah nilai $\alpha=5 \%$ maka semakin cukup bukti untuk menyatakan bahwa variabel bebas yang digunakan signifikan terhadap variabel tak bebasnya. Selain itu yang harus diperhatikan adalah pada nilai koefisien apakah sesuai dengan hipotesis awal yang telah dirumuskan.

\section{Interpretasi Model}

Dari hasil pengolahan data dengan menggunakan fixed effect model GLS crosssection weight sebagaimana Tabel 3 diketahui bahwa variabel yang secara signifikan mempengaruhi indeks pembangunan manusia (IPM) pada tiap-tiap tipologi wilayah pengembangan Kabupaten Malang pada $\alpha=5 \%$ meliputi: 1) Tipologi I: 3 variabel yaitu jumlah fasilitas kesehatan, kepadatan penduduk dan jumlah perawat-bidan; 2) Tipologi II: 2 variabel yaitu rasio sekolah terhadap siswa SD dan kepadatan penduduk; dan 3) Tipologi III: 1 variabel yaitu jumlah perawat-bidan. Untuk variabel lainnya tidak berpengaruh secara signifikan terhadap indeks pembangunan manusia (IPM) pada tiap-tiap tipologi.

Posisi dominan dua tipologi wilayah pengembangan yaitu tipologi I dan II dalam sebaran penduduk Kabupaten Malang menunjukkan kedudukan kedua tipologi tersebut sebagai pusat pertumbuhan. Hasil regresi panel data menunjukkan bahwa variabel kepadatan penduduk berpengaruh positif dan signifikan pada taraf nyata 5 persen terhadap IPM pada tipologi I dan II sesuai dengan hipotesis yang telah dibuat sebelumnya.

Tabel 3. Hasil estimasi faktor-faktor yang mempengaruhi IPM Kabupaten Malang menggunakan Fixed Effect Model GLS cross-section weight

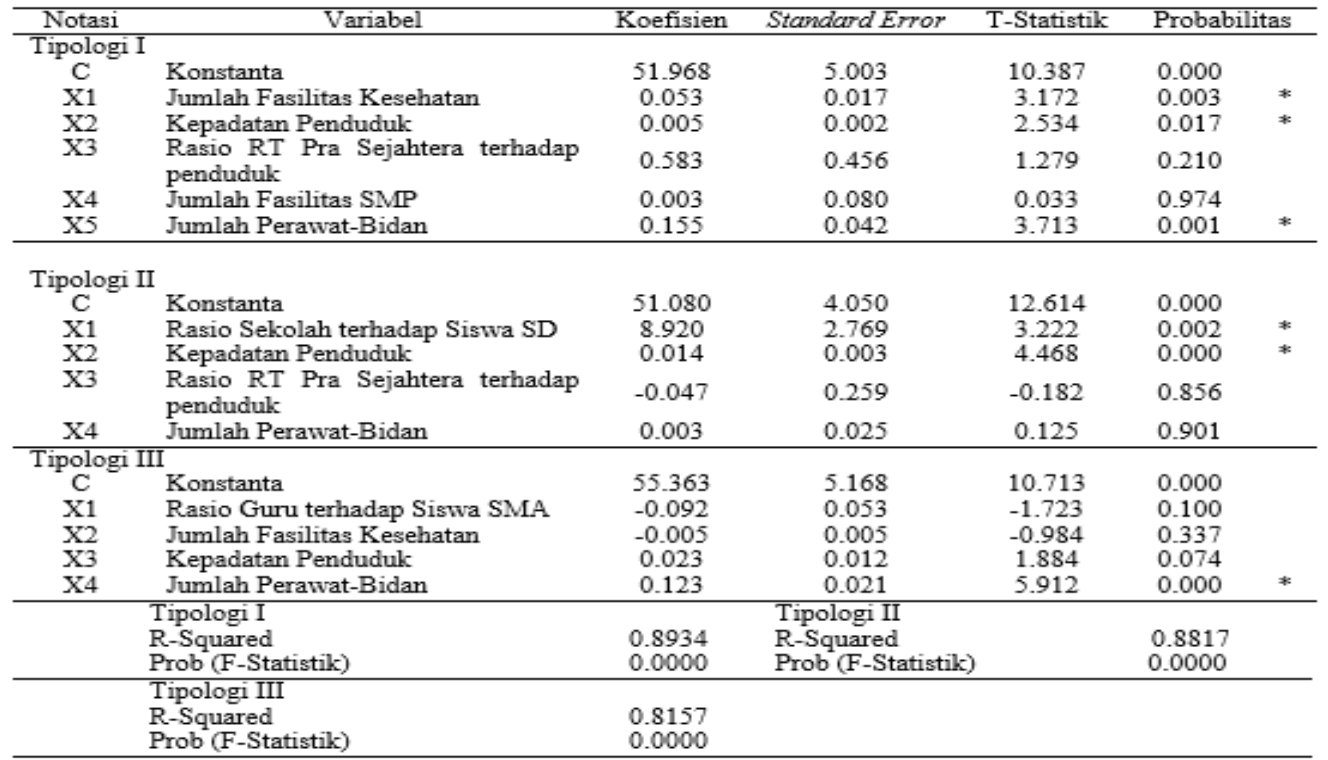

Sumber: Hasil pengolahan dengan EViews 6.0

Catatan: *) Signifikan pada $\alpha=5 \%$

Nilai koefisien regresi dari variabel kepadatan penduduk untuk: 1) Tipologi I sebesar 0.005 dengan probabilitas ( $p$-value) sebesar 0.017; dan 2) Tipologi II sebesar 0.014 dengan probabilitas ( $p$-value) sebesar 0.000. Secara spesifik dapat dinyatakan bahwa pada kondisi ceteris paribus, bila kepadatan penduduk pada tipologi I dan II meningkat sebesar 1 jiwa $/ \mathrm{km}^{2}$, maka IPM pada tipologi I akan meningkat 
sekitar 0.005 dan tipologi II meningkat sekitar 0.014 .

Kepadatan penduduk pada tipologi I dan II mendorong peningkatan IPM mengingat kedua tipologi ini ditinjau dari kondisi topografi lebih didominasi oleh wilayah datar sampai bergelombang dengan tingkat aksesibilitas yang cukup baik bila dibandingkan dengan wilayah pada tipologi III. Penduduk yang padat mengakibatkan terkonsentrasinya kegiatankegiatan ekonomi serta jangkauan pelayanan infrastruktur menjadi lebih efisien.

Hasil regresi panel data menunjukkan bahwa variabel rasio sekolah per siswa SD pada tipologi II berpengaruh positif dan signifikan pada taraf nyata 5 persen. Nilai koefisien regresi dari variabel rasio sekolah per siswa sebesar 8.920 dengan probabilitas ( $p$-value) sebesar 1.2. Secara spesifik dapat dinyatakan bahwa pada kondisi cateris paribus, bila rasio sekolah per siswa meningkat sebesar 1 satuan, maka IPM akan meningkat sekitar 8.920. Sesuai dengan data empiris tahun 2010-2014 rasio sekolah per siswa meningkat rata-rata setiap tahun sebesar 0.01-0.02 satuan.

Variabel pendidikan menjadi penting pada tipologi II mengingat jumlah penduduk yang padat dan jumlah sarana pendidikan yang masih belum memadai jika dibandingkan dengan jumlah penduduk yang dilayani. Jumlah sarana pendidikan tahun 2015 terbanyak berada pada tipologi II yaitu sejumlah 2.190 unit $(53,18 \%)$, disusul dengan tipologi I sejumlah 1.236 unit $(30,01 \%)$ dan tipologi III sejumlah 692 unit $(16,80 \%)$. Penambahan sarana pendidikan dan peningkatan akses pelayanan pendidikan terhadap masyarakat akan mendorong peningkatan IPM pada tipologi II ini.

Hasil regresi panel data menunjukkan bahwa variabel jumlah fasilitas kesehatan berpengaruh positif dan signifikan pada taraf nyata 5 persen terhadap IPM pada tipologi I sesuai dengan hipotesis yang telah dibuat sebelumnya. Nilai koefisien regresi dari variabel jumlah fasilitas kesehatan pada tipologi I sebesar 0.053 dengan probabilitas ( $p$-value) sebesar 1.3. Secara spesifik dapat dinyatakan bahwa pada kondisi ceteris paribus, bila jumlah fasilitas kesehatan pada tipologi I meningkat sebesar 1 unit, maka IPM pada tipologi I akan meningkat sekitar 0.053 .

Variabel kesehatan menjadi penting pada tipologi I mengingat jumlah penduduk yang padat, jumlah sarana kesehatan yang masih belum memadai jika dibandingkan dengan jumlah penduduk yang dilayani serta kondisi lingkungan yang memburuk karena urbanisasi.

Jumlah sarana kesehatan terbanyak berada pada tipologi II yaitu sejumlah 1.786 unit $(53,54 \%)$ disusul dengan tipologi I sejumlah 1.006 unit $(30,16 \%)$ dan tipologi III sejumlah 544 unit $(16,31 \%)$. Penambahan sarana kesehatan dan peningkatan akses pelayanan kesehatan terhadap masyarakat akan mendorong peningkatan IPM pada tipologi I ini.

Hasil regresi panel data menunjukkan bahwa variabel jumlah perawat-bidan berpengaruh positif dan signifikan pada taraf nyata 5\% terhadap IPM pada tipologi I dan III sesuai dengan hipotesis yang telah dibuat sebelumnya. Nilai koefisien regresi dari variabel jumlah perawat-bidan untuk: 1) Tipologi I sebesar 0.155 dengan probabilitas ( $p$-value) sebesar 0.001; dan 2) Tipologi III sebesar 0.123 dengan probabilitas ( $p$-value) sebesar 0.000 . Secara spesifik dapat dinyatakan bahwa pada kondisi ceteris paribus, bila jumlah perawatbidan pada tipologi I dan III meningkat sebesar 1 jiwa, maka IPM pada tipologi I akan meningkat sekitar 0.155 dan tipologi III meningkat sekitar 0.123 .

Variabel kesehatan menjadi penting pada tipologi III mengingat jumlah penduduk yang rendah dan fasilitas dan tenaga kesehatan yang terbatas (bukan karena faktor lingkungan). Jika dilihat dari jumlah tenaga kesehatan terutama perawat-bidan tahun 2015 terbanyak berada pada tipologi II yaitu sejumlah 634 orang $(54,80 \%)$ disusul dengan tipologi I sejumlah 294 orang $(25,41 \%)$ dan tipologi III sejumlah 229 orang $(19,79 \%)$. Walaupun ketersediaan tenaga kesehatan terutama perawat-bidan pada tipologi I dan III lebih sedikit daripada tipologi II namun penambahan tenaga kesehatan mampu meningkatkan akses pelayanan kesehatan 
terhadap masyarakat dan mendorong peningkatan IPM pada kedua tipologi ini.

\section{KESIMPULAN DAN REKOMENDASI}

Dari uraian di atas dapat disimpulkan hasil analisis panel data terhadap masing-masing tipologi, dapat diketahui bahwa aspek yang berpengaruh terhadap indeks pembangunan manusia pada tipologi I adalah aspek kependudukan dan kesehatan yang meliputi jumlah penduduk, sarana kesehatan dan tenaga kesehatan; tipologi II adalah aspek kependudukan dan pendidikan yang meliputi jumlah penduduk dan sarana pendidikan; serta tipologi III adalah aspek kesehatan yaitu jumlah tenaga kesehatan.

Untuk meningkatkan indeks pembangunan manusia (IPM) berbasis tipologi sistem wilayah pengembangan maka disarankan pada tipologi I perlu penambahan sarana kesehatan dan tenaga kesehatan serta peningkatan akses pelayanan kesehatan terhadap masyarakat; tipologi II perlu penambahan sarana pendidikan serta peningkatan akses pelayanan pendidikan terhadap masyarakat; dan tipologi III perlu penambahan tenaga kesehatan untuk bisa memberikan akses pelayanan kesehatan terhadap masyarakat.

\section{DAFTAR PUSTAKA}

Aji, S., Syarifudin, D., \& Ishak, R. F. (2014). Identifikasi tipologi wilayah perbatasan antar kabupaten/ kota dan indeks pembangunan manusia di provinsi jawa barat. Proceeding Presentasi Hasil Penelitian Hibah Program Desentralisasi, Sentralisasi dan Hibah Internal Unpas 2014, 145-149. Bandung: Lembaga Penelitian Universitas Pasundan.

Bhakti, N.A., Istiqomah, \& Suprapto. (2014). Analisis faktor-faktor yang mempengaruhi indeks pembangunan manusia di indonesia periode 2008-2012. Ekuitas: Jurnal Ekonomi dan Keuangan. 18 (4), 452-492.
Ginting, S. C. K., Lubis, I., \& Mahalli, K. (2008). Pembangunan Manusia di Indonesia dan Faktorfaktor yang Mempengaruhinya. WAHANA HIJAU Jurnal Perencanaan \& Pengembangan Wilayah. 4 (1), 17-24.

Hariyanto, A. (2006). Percepatan Pengembangan Wilayah melalui Strategi Implementasi Wilayah Pengembangan (WP) dan Hirarki Kota-Kota (Studi Kasus: Kabupaten Subang). Jurnal PWK Unisba. 21-51.

Hariyanto \&Tukidi. (2007). Konsep pengembangan wilayah dan penataan ruang Indonesia di era otonomi daerah. Jurnal Geografi. 4 (1), 1-10.

Iryanto. (2006). Perencanaan Pembangunan Kabupaten/Kota melalui Pendekatan Wilayah dan Kerja Sama Antardaerah. Wahana Hijau Jurnal Perencanaan \& Pengembangan Wilayah. 1 (3), 95-102.

Juhardi R.R, Hamidi, W., \& Syapsan. (2011). Studi Empiris Capaian MDGs di Provinsi Riau. Jurnal Sosial Ekonomi Pembangunan. I (3), 272-289.

Latifah, E. (2011). Harmonisasi Kebijakan Pengentasan Kemiskinan di Indonesia Yang Berorientasi pada Millenium Development Goals. Jurnal Dinamika Hukum. 11 (3), 391-401.

Maulana, R. \& Bowo, P. A. (2013). Pengaruh Pertumbuhan Ekonomi, Pendidikan dan Teknologi terhadap IPM Provinsi di Indonesia 2007-2011. Journal of Economics and Policy. 6 (2), 163-169.

Melliana, A. \& Zain, I. (2013). Analisis Statistika Faktor yang Mempengaruhi Indeks Pembangunan Manusia di Kabupaten/Kota Provinsi Jawa Timur dengan Menggunakan Regresi Panel. Jurnal Sains dan Seni Pomits. 2 (2), D237-D242.

Nachrowi, N. D. \& Usman, H. (2006). Pendekatan Populer dan Praktis Ekonometrika Untuk Analisis Ekonomi dan Keuangan. Jakarta: Lembaga Penerbit Fakultas Ekonomi, Universitas Indonesia.

Niu, S., Jia, Y., Wang, W., He, R., Hu, L., \& Liu Y. (2013). Electricity Consumption and Human Development Level: A Comparative Analysis Based on Panel Data for 50 Countries. Electrical Power and Energy Systems. 53 (2013), 338-347.

Nurhadi. (2012). Konsep Perwilayahan dan Teori Pembangunan dalam Geografi. Geomedia. 10 (1), 49-66.

Pratowo, N. I. (2012). Analisis Faktor-Faktor yang Berpengaruh terhadap Indeks Pembangunan Manusia. Jurnal Studi Ekonomi Indonesia. 1 (1), 15-31. 
Rustariyuni, S. D. (2014). Pengaruh Gini Ratio, Pengeluaran Non Makanan Per Kapita, Belanja Daerah dan Laju Pertumbuhan Ekonomi pada Indeks Pembangunan Manusia Kabupaten/Kota di Provinsi Bali Periode 2004-2012. PIRAMIDA. $X(1), 45-55$.

Rustiadi, E., Saefulhakim, S., \& Panuju, D. R. (2011). Perencanaan dan Pengembangan Wilayah. Bgor: Crestpent Press \& Yayasan Pustaka Obor Indonesia.

Shuai, C., Shen, L., Jiao, L., Wu, Y., \& Tan, Y. (2017). Identifying Key Impact Factors on Carbon Emission: Evidences from Panel and Time-Series Data of 125 Countries from 1990 to 2011. Applied Energy. 187 (2017), 310-325.

Spangenberg, J. H. (2015). The Corporate Human Development Index CHDI: A Tool For Corporate Social Sustainability Management and Reporting. Journal of Cleaner Production. xxx (2015), 1-11

Su, L., Zhang, Y., \& Wei, J. (2016). A Practical Test for Strict Exogeneity in Linear Panel Data Models with Fixed Effects. Economics Letters. 147 (2016), 27-31.

Winarno, W. W. (2015). Analisis Ekonometrika dan Statistika dengan EViews. Edisi ke-4. Yogyakarta : UPP STIM YKPN.

Vuković, D. \& Wei, L. (2010). Regional Competitiveness: the Case of Western China. Journal of the Geographical Institute, Serbian Academy of Sciences and Arts. 60 (1), 107-124. 